\title{
The Citrus Route Revealed: From Southeast Asia into the Mediterranean
}

\author{
Dafna Langgut ${ }^{1}$ \\ The Laboratory of Archaeobotany and Ancient Environments, The Sonia and Marco Nadler Institute of Archaeology, \\ Tel Aviv University, Israel
}

Additional index words. citrus, Citrus medica, citron, lemon, botanical remains, elite products

\begin{abstract}
Today, citrus orchards are a major component of the Mediterranean landscape and one of the most important cultivated fruits in the region; however, citrus is not native to the Mediterranean Basin, but originated in Southeast Asia. Here, the route of the spread and diversification of citrus is traced through the use of reliable historical information (ancient texts, art, and artifacts such as wall paintings and coins) and archaeobotanical remains such as fossil pollen grains, charcoals, seeds, and other fruit remains. These botanical remains are evaluated for their reliability (in terms of identification, archaeological context, and dating) and possible interpretations. Citrus medica (citron) was the first citrus to spread west, apparently through Persia and the Southern Levant (remains were found in a Persian royal garden near Jerusalem dated to the fifth and fourth centuries BC) and then to the western Mediterranean (early Roman period, $\approx$ third and second centuries $\mathrm{BC}$ ). In the latter region, seeds and pollen remains of citron were found in gardens owned by the affluent in the Vesuvius area and Rome. The earliest lemon $(C$. limon) botanical remains were found in the Forum Romanum (Rome) and are dated to the late first century BC/early first century AD. It seems, therefore, that lemon was the second citrus species introduced to the Mediterranean. The contexts of the botanical remains, in relation to elite gardens, show that in antiquity, both citrus and lemon were products representing high social status. Sour orange $(C$. aurantium), lime ( $C$. aurantifolia), and pummelo ( $C$. maxima) did not reach the Mediterranean until the 10th century AD, after the Islamic conquest. Sweet orange $(C$. sinesis) was introduced during the second half of the 15 th century AD, probably via the trade route established by the Genoese, and later (16th century AD) by the Portuguese. The mandarin ( $C$. reticulata) reached the Mediterranean only in the early 19th century. While citron and lemon arrived in the Mediterranean as elite products, all other citrus fruit most probably spread for economic reasons.
\end{abstract}

Today, various citrus fruits (Citrus spp. Rutaceae) are among the most important commercial fruit crops of the Mediterranean, but they are not native to the region. Citrus is believed to have originated in northeastern India, southwestern China, Burma, and the Malay archipelago, and subsequently dispersed into other lands in southeast Asia, accompanied by local differentiation (e.g., Gmitter and Hu, 1990; Scora, 1975; Webber, 1967). The three edible ancestral species of the main commercial citrus types are citron (C. medica), pummelo (C. maxima), and mandarin ( $C$. reticulata). This argument was made four decades ago by several scholars (Barrett and Rhodes, 1976; Scora, 1975) based on morphological and biochemical characteristics and is supported today by genetic studies proving that other edible citrus "species" are in fact hybrids (e.g., Barkley et al., 2006; Curk et al., 2016; Federici et al., 1998; Nicolosi et al., 2000, 2005; Pang et al., 2007; Wu et al., 2014).

Received for publication 10 June 2016. Accepted for publication 21 July 2016.

This article was presented as part of a workshop titled "Fresh Perspectives on Citrus History" during the ASHS Annual Conference, which was held on 4-7 August, 2015, in New Orleans, LA.

I am grateful to Marijke van der Veen and David Karp for the exchange of thoughts and ideas. Oded Lipschits provided assistance with the interpretation of Biblical and other Jewish texts, and Itamar Ben-Ezra and Mark Cavanagh helped with figures preparation. Photographs by Clara Amit were made available thanks to the courtesy of the Israel Antiquities Authority.

${ }^{1}$ Corresponding author. E-mail: langgut@post.tau. ac.il.
From the 16th century to the 20th century, many scholars tried to document the history of citrus forms and their dispersal from eastern Asia, including Dalechamps (1587), de l'Écluse (1601), Ferrari (1646), Gallesio (1811), Tolkowsky (1938, 1966), Andrews (1961), Webber (1967), Watson (1983), and Calabrese (1998). These studies greatly enriched our knowledge of the diversification of citrus forms and their spread to the Mediterranean. However, some of the evidence was misused, misinterpreted, or both, especially in the case of the botanical remains from archaeological excavations or geological sediments. The current study reevaluates some of the contradictory evidence in order to arrive at a clear and accurate picture.

This review article, therefore, aims to integrate recent information concerning the history of citrus together with all previous reliable information to reveal and revise the westward migration route of citrus. In addition, this article will try to trace the reasons behind the introduction of the different citrus forms into the Mediterranean, distinguishing elite products from cash crops.

\section{Material and Methods}

This article combines the following line of evidence to trace the route of the western diffusion of citrus: botanical remains, art artifacts, and ancient texts.

\section{Botanical remains}

The botanical remains discussed in this study include seeds (as well as some other fruit remains such as rinds), wood, charcoals, and fossil pollen grains. While the first two types of evidence are derived from archaeological sites, pollen is also extracted from sediment cores, aiming to reconstruct past vegetation and environmental conditions.

In this study, the validity of some of the botanical remains of citrus is evaluated for their reliability in terms of the following: 1) identification, 2) archaeological context, and 3) dating.

1) Identification - recent studies indicate that citrus seeds sometimes appear difficult to recognize because of their morphological variability, changes arising from preservation processes (Pagnoux et al., 2013), and their relatively poor state of preservation in the first place, mainly because citrus seeds are oily. The problem also lies in the similarity of the general morphology of citrus seeds to seeds of other taxa (e.g., Maloideae types - subfamily of the Rosaceae), especially when mineralized (Coubray et al., 2010; Pagnoux et al., 2013). Hence, more advanced methods are recommended when identifying citrus seeds, such as high-resolution microtomography technology, which enables 2D and $3 \mathrm{D}$ simulation to a scale of microns. By using this identification method, Coubray et al. (2010) reexamined the seeds from the sixth century BC site of Stipe dei Cavalli, Ischia, Italy, previously investigated by Coubray (1996). Their reexamination did not support the original attribution to citrus seeds and they should be identified as Sorbus domestica, a member of the Maloideae (Coubray et al., 2010). Pollen identification is more accurate than seed identification in the case of citrus; some recent studies even show that it is possible to distinguish Citrus to the species 
level, preferably by using a scanning electron microscope (Bui Thi and Girard, 2014; Russo-Ermolli et al., in press; Xianghong, 1982). In most cases, the identification of Citrus wood and charcoal remains is possible with high certainty only to the genus level (Schweingruber, 1990).

2) Archaeological context - great attention must be paid to the quality associations between botanical remains and the archaeological contexts from which the samples originate; the botanical remains should come from a secure context in terms of stratigraphy to prevent contamination or mixing with previous and later archaeological layers.

3) Dating - a critical issue in archaeology in general and in archaeobotany in particular; during historical periods, the dating of archaeological excavations relies mainly on typology of artifacts (such as pottery and coins) and ${ }^{14} \mathrm{C}$ radiocarbon dating of organic material such as wood remains. More accurate ${ }^{14} \mathrm{C}$ dating can be achieved by radiocarbon dating of shortlived macrobotanical remains such as seeds (to avoid the age of the wood sample itself), when they are clearly associated with the relevant archaeological context.

\section{Art artifacts}

Citrus fruits and trees appear in several forms of ancient artifacts, namely reliefs, wall paintings, mosaics, and coins. The main problems are related to the interpretation of the appearance of citrus on those objects in terms of the following: 1) the significance of their presence and 2) secure identification.

1) The appearance of citrus on ancient art and artifacts does not necessarily provide evidence of actual cultivation, but can suggest familiarity with citrus.

2) Citrus identification is particularly doubtful in the case of wall reliefs. Several suggestions were previously made connecting fruits appearing on ancient reliefs to citron. For example, the French archaeologist Loret (1891) claimed that at the Karnak Temple, Egypt, which was built in the time of Thutmosis III (15th century $\mathrm{BC}$ ), citrons are evident in the relief. Another example comes from ninth century BC Assyrian reliefs in which coneshaped objects held by human figures were identified by Bonavia (1894) as citrons. In my opinion, it is impossible to clearly define what was depicted in those reliefs. Other scholars reached the same conclusions when they failed to find a clear connection between the reliefs and the citron (e.g., Amar, 2009; Andrews, 1961). Since these two types of evidence are considered unreliable, they will not be discussed further.

\section{Ancient texts}

In this study, several sources of ancient texts have been used such as Jewish, GrecoRoman, and Arabic texts; these written sources were recently reviewed, respectively
(Langgut, 2015; Pagnoux et al., 2013; Ramón-Laca, 2003). In the course of this track, some use of philology will be made when relevant.

\section{Cultivation versus familiarity}

The presence of pollen grains of insectpollinated citrus is direct evidence of its actual growth in a given region (see below), unlike other archaeobotanical remains (seeds, rinds, charcoal and wood remains, and chemical analysis) that may reflect importation of fruit, small wooden objects, or even timber rather than the actual growing of the tree. In addition, since citrus plants are insect pollinated, they have low pollen dispersal efficiency. The occurrence of citrus pollen grains in a palynological spectrum is therefore direct evidence that it actually grew in the vicinity of the site in which it was found. As mentioned above, the occurrence of citrus in a wall painting may derive from familiarity with the fruit or even from foreign art experts hired to decorate a building and not necessarily on actual cultivation in a certain region.

\section{Results and Discussion}

Different characteristics of each of the citrus species discussed in this article are summarized in Table 1. The assumed date of introduction into the Mediterranean Basin and its possible causes are also presented in this table and discussed in detail in the

Table 1 . The westward migration of citrus species.

\begin{tabular}{|c|c|c|c|c|}
\hline Citrus species & Truespecies/Hybrid & Area of origin & $\begin{array}{l}\text { First "secure" evidence of cultivation } \\
\text { in the Mediterranean Basin }\end{array}$ & Diffusion mechanism \\
\hline Lemon C. limon & Hybrid & $\begin{array}{l}\text { Eastern India, Assam, and } \\
\quad \text { upper Burma (Scora, 1975) }\end{array}$ & $\begin{array}{l}\text { Late first century BC and early first } \\
\text { century AD (Pagnoux et al., 2013) }\end{array}$ & $\begin{array}{l}\text { Imported to the Western } \\
\text { Mediterranean by the } \\
\text { Roman empire for luxury } \\
\text { gardens (elite product) }\end{array}$ \\
\hline Sour orange $C$. aurantium & Hybrid & $\begin{array}{l}\text { Southernmost China and } \\
\text { northern Indo-China } \\
\text { (Weisskopf and Fuller, 2013) }\end{array}$ & $\begin{array}{l}\text { 10th century AD (Ramón-Laca, } 2003 \\
\text { and references therein) }\end{array}$ & $\begin{array}{l}\text { Introduced after the Islamic } \\
\text { conquest (cash crop) }\end{array}$ \\
\hline Lime C. aurantifolia & Hybrid & $\begin{array}{l}\text { Malaysia and East Indian } \\
\text { archipelago (Scora, 1975; } \\
\text { Weisskopf and Fuller, 2013) }\end{array}$ & $\begin{array}{l}\text { 11th century AD (Ramón-Laca, 2003; } \\
\text { van der Veen, 2011) }\end{array}$ & $\begin{array}{l}\text { Introduced after the Islamic } \\
\text { conquest (cash crop) }\end{array}$ \\
\hline Sweet orange $C$. sinesis & Hybrid & $\begin{array}{l}\text { Southern China and northern } \\
\text { India (Davidson, 2006) }\end{array}$ & $\begin{array}{l}\text { After mid-15th century AD (Ramón- } \\
\text { Laca, } 2003 \text { and references therein) }\end{array}$ & $\begin{array}{l}\text { The arrival is linked with the } \\
\text { trade route established by } \\
\text { the Genoese and later } \\
\text { (from the 16th century } \\
\text { AD) by the Portuguese } \\
\text { (cash crop) }\end{array}$ \\
\hline Mandarin C. reticulata & Truespecies & $\begin{array}{l}\text { China and Northeast India } \\
\text { (Scora, 1975; Spiegel-Roy } \\
\text { and Goldschmidt, 1996) }\end{array}$ & Early 19th century AD (Davidson, 2006) & $\begin{array}{l}\text { Brought to England and from } \\
\text { there distributed to Italy } \\
\text { and other Mediterranean } \\
\text { countries (cash crop) }\end{array}$ \\
\hline
\end{tabular}


following text. Most efforts were devoted to gathering information concerning the arrival of the citron because this fruit was the first citrus to reach the Mediterranean and since its exact date of arrival has been the subject of a longstanding debate, which is still ongoing.

\section{Citron (C. medica)}

The citron was the first citrus fruit to reach the Mediterranean, probably via Persia (Langgut, 2015; Langgut et al., 2013; Zohary et al., 2012). It originated in northeastern India or northern Southeast Asia, in the area from Assam, Myanmar, and Yunnan to the eastern Himalayan foothills, where it was probably also first domesticated (Fig. 1A; Fuller et al., 2011). This region is further west than the areas of origin of the other citrus species (Weisskopf and Fuller, 2013). Gur (1974) suggested that $C$. medica made its way from India to Afghanistan, Persia, Syria, Israel, and Egypt. The name may also shed some light on citron's origin and diffusion route: In Hindi the citron is called torange, in Persian it is called toronge and later etronge, in Hebrew it is called etrog, in Aramaic etronga or etroga, and in Arabic turug or eturug. In Coptic the citron is ghitri, in Greek kitrea and kitrion, and in Latin the word citrus was used to name the tree and citreum or citrium for the fruit. The word medica in the Latin name (Citrus medica) may also suggest its Persian (Median) origin rather than its use for medical purposes. Tolkowsky (1966) mentions that during the 1950s and 1960s, C. medica trees that match Theophrastus's description were grown in the Gilan province in Persia (Theophrastus, 1916), which was part of ancient Media [Theophrastus of Eresos (372-287 BC) - the great Greek botanist who wrote the Enquiry into Plants (Historia Plantarum) which contains elaborate and accurate description of Asian flora; a description of the citron tree appears in the fourth chapter of the book, which is dated to $\approx 310 \mathrm{BC}$.

Archaeobotanical evidence indicates that in the Nippur archaeological excavation, in the south of ancient Babylonia, citrus seeds dating to the Sumerian period $(\approx 2000 \mathrm{BC})$ were discovered (cited by Bonavia, 1894: 68 ). Since the seeds found in the excavation were charred, they can only be identified as Citrus, and specific species cannot be determined. Tolkowsky (1966) pointed out that the period to which these seeds belong cannot be precisely dated. Furthermore, he emphasized that their presence in Nippur does not necessarily indicate that the tree from which they came was cultivated in Babylonia at that time. If the citron tree had grown there on a limited scale in ancient times, Tolkowsky (1966) believed it would have been a common tree during Alexander the Great's conquest of the region in the late fourth century BC. The Greek botanists accompanying Alexander reported that the citron was grown only in Persia and Media (described in Theophrastus' book). Tolkowsky (1966) therefore found the evidence from Nippur to be inconclusive; he claimed that if this seed assemblage was identified correctly, they were probably citron seeds brought to Nippur either as an offering to a divinity or as a gift to a king. Since the seeds were not dated directly, their age being assessed only by their archaeological context, which seems to be insecure, and since recent investigations show that the identification of citrus seeds requires advanced methods (Coubray et al., 2010; Pagnoux et al., 2013), which were not available at that time, it is therefore possible that the seeds were misidentified. This is also the case with the seeds which came from the archaeological site Hala Sultan Tekke (Cyprus), where seeds that resemble Citrus were discovered in a layer dated to the 12 th century BC, but the exact species could not be identified (Hjelmqvist, 1979). Thus, these remains have not yet been directly dated to confirm their antiquity (e.g., by accelerator mass spectrometry radiocarbon dating; Zohary et al., 2012). Furthermore, those seeds

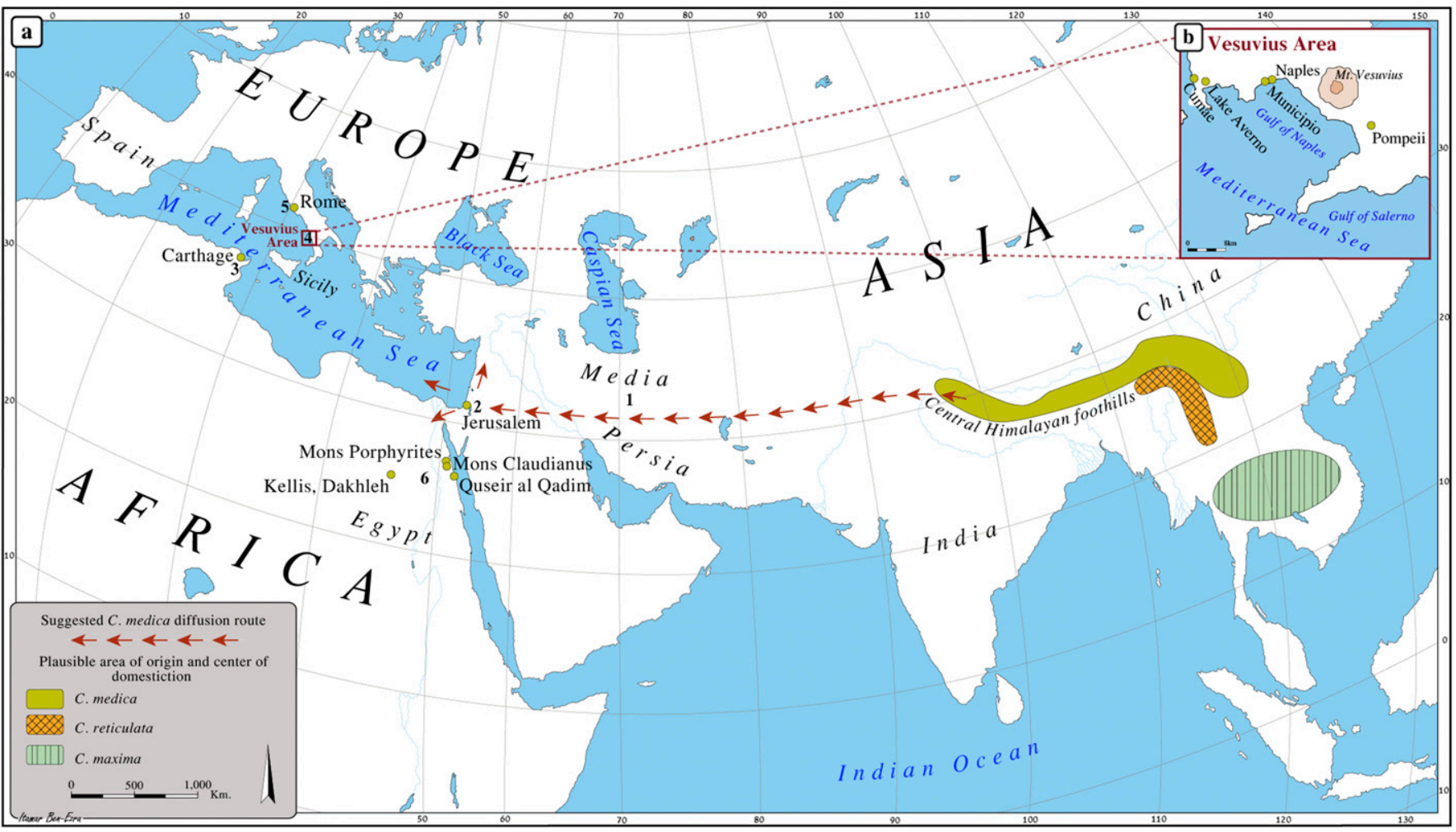

Fig. 1. (A) Map showing the plausible area of origin and center of domestication of $C$. medica, $C$. reticulata, and $C$. maxima [modified after Weisskopf and Fuller (2013)], together with Near Eastern archaeological sites from which "secure" C. medica botanical remains were recovered: 1) textual evidence from Media and Persia written by Theophrastus, Enquiry into Plants, describing citron cultivation during the fourth century BC; 2) pollen, Ramat Rahel near Jerusalem, fifth and fourth centuries BC; 3) pollen, Carthage fourth and early third centuries BC; 4) pollen, seeds, and charcoal remains from sites in the Vesuvius area (B) starting to appear since the third and second centuries BC; 5) seeds and fruit remain of Citrus, most probably of C. limon which marks its earliest appearance outside Asia, the Forum Romanum, Rome; 6) seed remains from Roman sites in the Egyptian Desert, first and fourth centuries AD. (B) The Vesuvius area where botanical remains of both Citrus medica and C. limon were identified. In Cumae, Lake Averno, and Municipio excavations, Citrus pollen was extracted from sediment sections. In varied sites in Pompeii and Naples, Citrus botanical remains were mainly linked to important gardens. 
originated from an insecure archaeological context because they were found in an unsealed stratum. Since the remains from Cyprus could not be found, the attempts to reexamine the seed assemblage were unfortunately not successful (D. Moster, personal communication).

Even if we accept the indefinite identification and inconclusive dating and context of the remains from Nippur and Cyprus, the presence of citrus seeds can only indicate that the fruit itself was present at the site, but this is not necessarily the proof that the tree was grown locally. Indeed, it appears that the citron was considered a valuable commodity since ancient times because of its healing qualities, symbolic use, and pleasant smell on the one hand and its rarity on the other (e.g., Zohary et al., 2012), possibly making the citron known to the people in the region by reputation throughout antiquity. Liran (2013) reached a similar conclusion, suggesting that the citron was a rare commodity that only the rich could afford. In addition, citron, unlike other citrus species is largely inedible and can be preserved for months because of its thick albedo. Therefore, it is likely that because of its relatively long shelf life, citron was used in antiquity as a long-distance elite trading product.

Recently published pollen findings from a Persian royal garden next to a lavish palace excavated at the Ramat Rahel site near Jerusalem, when the area was a Persian province (Lipschits et al., 2012) shed new light on the dating of the cultivation of $C$. medica in the Mediterranean (Langgut et al., 2013). While examining the plaster of one of the pools in the garden, dating to the fifth and fourth centuries $\mathrm{BC}$, fossilized $C$. medica pollen grains were identified. They had been trapped in one of the plaster layers (various structures within the garden were plastered in several layers, probably because of ongoing maintenance). The unique palynological spectra extracted from this plaster layer included, in addition to $C$. medica, other palynological evidence of trees introduced from remote parts of the Persian empire, special trees highly valued by the ruling Persian authorities [e.g., the cedar of Lebanon (Cedrus libani)], together with native fruit trees and ornamentals. It should be noted that although citrus pollen is hardly ever airborne, it appears at high frequencies within Ramat Rahel's palynological assemblages (up to $32 \%$ ). During most of the period (second half of the fifth century $\mathrm{BC}$ and during the fourth century $\mathrm{BC}$ ), the reconstructed climate conditions for the region (southern Levant) were relatively humid (Langgut and Lipschits, 2017), but the citron still probably required summer irrigation.

The next botanical evidence in chronological order derives from the sediment of the Punic port of Carthage (Tunis, North Africa) where a single pollen grain from the level contemporary with the fourth and early third centuries BC was extracted. According to van Zeist et al. (2001), this palynological evidence suggests that citrus was cultivated at this time in Carthage. In my opinion, due to the occurrence of only one pollen grain, the significance of this datum is very limited.

The occurrence of pollen, seed, and fruit remains of citron in several sites throughout the Mediterranean dated to the Roman period attests that by that time citron became much more known in the region. In the eastern Mediterranean, seeds and fruit remains from secure contexts were retrieved from several Roman settlements in Egyptian remote desert locations (Fig. 1A) dating to the first-fourth centuries AD [Quseir al-Qadim (van der Veen, 2011), Mons Porphyrites (van der Veen and Tabinor, 2007), Kellis, Dakhleh (Thanheiser et al., 2002), and Mons Claudianus (van der Veen, 1996, 2001)]; within the latter site not only $C$. medica seeds were found but also one near-complete fruit. Since the remains were desiccated, they were very well preserved. In the western Mediterranean, a relatively rich ensemble of both microbotanical and macrobotanical remains of $C$. medica is available, mainly from the Vesuvius area, which even predates the assemblage from Egypt. The earliest western Mediterranean archaeobotanical evidence is from Pompeii from a context dated to the third and second centuries $\mathrm{BC}$, where several mineralized seeds of $C$. medica were found (Fiorentino and Marinò, 2008). A single mineralized seed was recovered from the second phase of the House of Hercules and Ebe's Wedding, dating from the first half of the second century BC (Ciaraldi, 2007); Mariotti-Lippi (2000) extracted citrus pollen (most probably of $C$. medica and $C$. limon) from the garden of this house. Another mineralized seed was recovered from the House of the Vestals from a phase dated to the second half of the second century BC (Ciaraldi, 2007). Pollen identified as belonging to $C$. medica and $C$. limon was also recovered from Oplontis from a sediment sample dated to somewhere between the first century $\mathrm{BC}$ and the first century AD (Russo-Ermolli and Messager, in press). The Egyptian finds mentioned previously are more recent in comparison with the Italian finds. According to Pagnoux et al. (2013), one can therefore assume that the Romans played an important role in the spread of citrus into Egypt. A similar scenario was recently suggested in another eastern Mediterranean case, where a possible Roman influence on the vegetation of the Herodian garden at Caesarea was identified (Langgut et al., 2015).

Citrus pollen was also extracted from several sediment records taken from the Gulf of Naples (Cumae, Lake Averno, and Municipio excavation; Fig. 1B). In the relatively well-dated Municipio section, pollen grains identified as Citrus were recovered from several levels dated to the first century $\mathrm{AD}$; Citrus pollen in previous or later levels was not present (Russo-Ermolli et al., 2014). Six pollen grains that were suggested to belong to C. medica or C. limon from a stratum dated to the Roman period were recognized in a Lake Averno sequence (Grüger and Thulin, 1998;
Grüger et al., 2002). The case of the Cumae sediment record is more complicated because of chronological uncertainties (Bui Thi and Girard, 2014). Citrus pollen (not identified to the species level) starts to appear somewhere between two available ${ }^{14} \mathrm{C}$ dates (but not right at the beginning), which covers a time interval from the mid-8th century $\mathrm{BC}$ to the second century $\mathrm{AD}$. The palynological diagram presented by Bui Thi and Girard (2014, Fig. 4.13) is not consecutive, and no explanation is given by the authors. One explanation may be related to preservation issues as was the case with the lowermost and uppermost parts of the Municipio section, which were pollen barren (levels dated to the third and second centuries $\mathrm{BC}$ and the sixth century $\mathrm{AD}$, respectively; Russo-Ermolli et al., 2014). Another explanation is mentioned by Grüger and Thulin (1998) in relation to their nearby record. The authors point out that hiatuses can be the result of regional earthquakes. Seismic events can also cause mixing of sediments, meaning that the pollen is not in situ. This possible disturbance may lead to palynological and chronological uncertainties within the Gulf of Naples' sediments.

Because of the lack of a robust chronological framework in the Cumae record, the dating of the first appearance of citrus pollen should rely on a correlation with the betterdated nearby pollen records [Lake Averno (Grüger and Thulin, 1998; Grüger et al., 2002), and the Municipio section (RussoErmolli et al., 2014)]; it therefore should not be dated before the Roman period. This suggestion accords well with the other citrus botanical remains that their first appearance in the Vesuvius area is dated to the third and second centuries BC (mentioned previously). The palynological evidence from Cumae cannot therefore be considered as the earliest presence of Citrus within the Italian peninsula as was suggested by several scholars (e.g., Pagnoux et al., 2013). This is also the case with another early southern Italian find, a citrus-like fruit, which was discovered in a funerary offering dating back to the sixth century BC on the southern Italian island of Ischia, which was reidentified as Maloideae by using more advanced identification methods (Coubray et al., 2010).

Textual evidence. The first textual evidence that may refer to the citron in Western sources was probably in the play Boiotis written by Antiphanes, an important writer of Middle Attic comedy (408-334 BC). Only a short part of this play survived by being cited several centuries later in the Deipnosophistae ("philosophers at dinner") written by Athenaeus in the early third century AD. The citron is not mentioned directly by name; just good looking and very delicious apples are described as part of a delivery from the Persian ruler, and it is explained as a unique fruit, very rare and therefore very expensive. Citron is also mentioned in the Deipnosophistae in another occasion as an effective antidote to any kind of poison, based on a story from Egypt given by the Greek philosopher Democritus (460-370 BC). This 
story seems to have inspired later authors such as Virgil and Pliny.

Several decades later $(\approx 310 \mathrm{BC})$, a much more reliable written source is available where a precise description of the citron from Media and Persia is given by Theophrastus in his book Enquiry into Plants:

"...And in general the lands of the East and South appear to have peculiar plants, as they have peculiar animals; for instance, Media and Persia have, among many others, that which is called the 'Median' or 'Persian apple'. This tree has a leaf like to and almost identical with that of the Arbutus, but it has thorns like those of the pear or white-thorn, which however are smooth and very sharp and strong. The 'apple' is not eaten, but it is very fragrant, as also is the leaf of the tree. And if the 'apple' is placed among clothes, it keeps them from being moth-eaten. It is also useful when one has drunk deadly poison; for being given in wine it upsets the stomach and brings up the poison..."

The text continues, giving exact instructions on how to grow the tree along with two key observations: the first being the tree's unique quality of bearing fruit during several seasons - making the citron tree a symbol of an eternal spring and of fertility and inspiring many poets and artists (this means, new fruit may grow on the same tree alongside fruit that grew during the previous year). The second observation has to do with the tree's flowers having a persistent style, which develops in citrons from the style and the stigma and making them more fertile as opposed to other flowers found to be sterile; in other Citrus species, this part degenerates. From a different piece written by Theophrastus, it appears that the discovery of sterile flowers with no persistent style was first made by Persian gardeners, who informed the Greek botanists (Tolkowsky, 1966). The Arbutus mentioned in Theophrastus's text is related to the eastern strawberry tree-Arbutus andrachne. Tolkowsky (1966) holds that the description of the citron leaf as having a round base and a pointed end, much like the Arbutus, eliminates any intent to perhaps refer to a different Citrus because they all have either winged petioles or very narrow chisel-shaped leaves. The pear within this text is related to the wild Syrian pear, Pyrus syriaca.

Scholars maintain that Theophrastus's emphasis that the tree grew in Media and Persia is further evidence that before $\approx 300 \mathrm{BC}$, the citron was not widely cultivated outside Media and Persia (e.g., Tolkowsky, 1966). Theophrastus's descriptions in Enquiry into Plants are based on observations by a number of Greek scholars who accompanied Alexander the Great and his army on all their campaigns and conquests through Asia Minor, Syria, Israel, Egypt, and Persia and even reached the region that is now Pakistan.
If so, they passed twice through the area west of Persia and did not mention observing the growing of citron trees. This leads to the conclusion that the citron tree was limited to the Iranian plateau and had not yet been cultivated west of there. On the other hand, Theophrastus did not describe the fruit itself, but rather its characteristics, which may suggest the citron fruit was known to the Greeks, but was not cultivated in their homelands.

Slightly before $37 \mathrm{BC}$, the citron was still described as an exotic fruit; the Roman poet Virgil describes the citron in his Georgics under the name Median apple, writing that its juice is an excellent remedy against poisons and that it has scented oil. Pliny the Elder in his encyclopedia Natural History (77-79 AD) gave the citron several names such as malus Assyria, malus medica, and citrus. He described its use as a medicine, poison antidote, and perfume, and as offering protection from moths. Pliny explained that because of its great medical values, various nations have tried to acclimatize it in their own countries, importing it in clay vessels provided with breathing holes for the roots, but it has refused to grow except in Media and Persia. He also mentioned that no other tree is so highly praised in Media. A more detailed survey of the Greco-Roman written sources of citron (and other citrus species) can be found in Pagnoux et al. (2013).

The citron in the Hebrew Bible and Jewish tradition. Today, citron is one of the four species which are used in the Jewish feast of Tabernacles (Sukkot). The verse in Leviticus 23:40 instructing the holding of the four species ("And ye shall take you on the first day the fruit of goodly trees, branches of palm trees, and the boughs of thick trees, and willows of the brook; and ye shall rejoice before the Lord your God seven days") clearly refers to two known species (willow and palm), but researchers have found it difficult to determine whether "the fruit of goodly trees" and "boughs of thick trees" refer to specific species or can be summarized as general instructions. The phrase "fruit of goodly trees" is a translation of the Hebrew phrase "pri etz hadar." Hadar in Hebrew means citrus but it is also a noun with the meaning of "glory" or "grandeur," which is typical of the poetry and prophecy in the Hebrew Bible, and therefore, the phrase "fruit of goodly trees" does not necessarily point to a specific tree. Indeed, the Septuagint (third century BC) determined that the phrase consists of a noun referring to a grand and delightful fruit. This appears to be the intention in Leviticus 27:30 and in Nehemiah $10: 36$, where the verses do not refer to any specific kind of tree. The phrase "fruit of goodly trees" is not mentioned in the description on the feast of Tabernacles in Nehemiah 8:13-15 where five different species are mentioned. Within the description, in the Books of the Maccabees 2 10:6-7, there is no mention of "the fruit of goodly trees" but rather "ivy-wreathed wands and beautiful branches and also fronds of palm" (Schwartz, 2005).

Starting in the first century $\mathrm{AD}$, there is a significant change in texts in which the four species used in the feast of Tabernacles are defined as palm, willow, myrtle, and citron. In Antiquities of the Jews (late first century AD), Flavius Josephus describes how the Jews threw citrons at Alexander Jannaeus for disrespecting the libation ritual (compare with Mishna tractate Sukkah 4:9). Documents of Chazal from this period indicate that the citron was fully accepted as part of the Tabernacles holiday tradition, with no mention of any kind of objection (Amar, 2012:108-109; Isaac, 1959:182). Therefore, it seems that before the first century AD, other traditions were not practiced. A detailed survey of the Jewish written sources of citron was recently published by Langgut (2015).

Rigid specifications were laid down by the rabbis to which all citrons used for the holiday ritual had to conform the following: the fruit must be fresh, its skin must be undamaged, the stigma and style which develop the persistent style must be in place, and at least the base of the stalk must be attached to the fruit. According to Isaac (1959:183), because of these requirements, the Jews took citrons into the Mediterranean as they formed the early communities of the Diaspora, since the beginning of the Christian era.

Though the shape of citrons may differ very much from one another (Goldschmidt, 1976), there are several artifacts which clearly corroborate the textual evidence indicating that by the first century AD, the citron was a fixed element in the feast of Tabernacles: on coins of the fourth year of the Great Jewish Revolt (69-70 AD, also called the First Jewish-Roman War), two citron fruits appear alongside a palm branch (Fig. 2A). Several decades later, the citron was depicted on a coin again, during the revolt of Simon Bar Kokhba (132-136 AD), together with the other three species which are used in the Feast
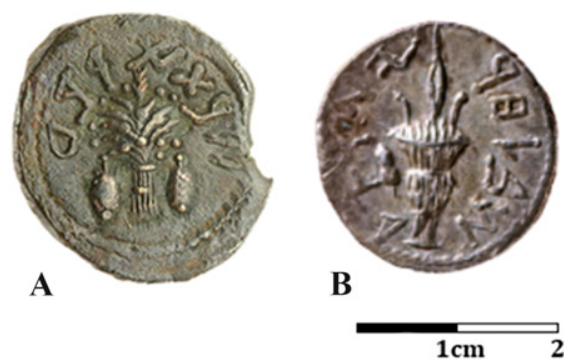

Fig. 2. (A) Citron fruits alongside a palm branch on a coin of the fourth year of the Great Revolt (69-70 AD). (B) Citron appears on a coin from the time of Simon bar Kokhba's revolt (132$136 \mathrm{AD})$, together with the other three species which are used in the Feast of Tabernacles. Note that according to Bar-Joseph (1996), the citron shows malformation symptom similar to those caused by viroid disease. Photograph by Clara Amit was made available thanks to the courtesy of the Israel Antiquities Authority. 
of Tabernacles (Fig. 2B); citron also appears on oil lamps which were found in ancient Israel, dated to the same period (Sussman, 1972). Later, citrons are seen in the DuraEuropos synagogue wall paintings in Syria (before $256 \mathrm{AD}$ ) in the decoration above the Torah niche (Kraeling, 1956). From the fourth century $\mathrm{AD}$, during the early Byzantine era, citron appears not only in synagogue mosaic pavements, lintels, and screens but also in many Christian mosaics in Israel and Jordan (see review by Ben-Sasson, 2012).

It is interesting to note that in some of these Byzantine mosaics, the citron fruits appear with "thin hips"; according to BarJoseph (1996), this shows malformation similar to that caused by viroid infection (viroids are the smallest disease-causing organisms that attack plants). For example, two citron fruits alongside a menorah in a sixth-century AD mosaic from the Maon Synagogue (Negev Desert, Israel) appear with such symptoms of viroid infection (Fig. 3). Similar symptoms were already present on the second century AD Bar Kokhba coins mentioned previously (Fig. 2B). From the same period, on a stone from a synagogue in Priene, Asia Minor, a citron with similar feature is depicted (Isaac, 1959, Fig. 5). The first viroid was discovered in 1978, and it is often stated that viroids have developed only in the last 100 years. Yet, these findings indicate, with

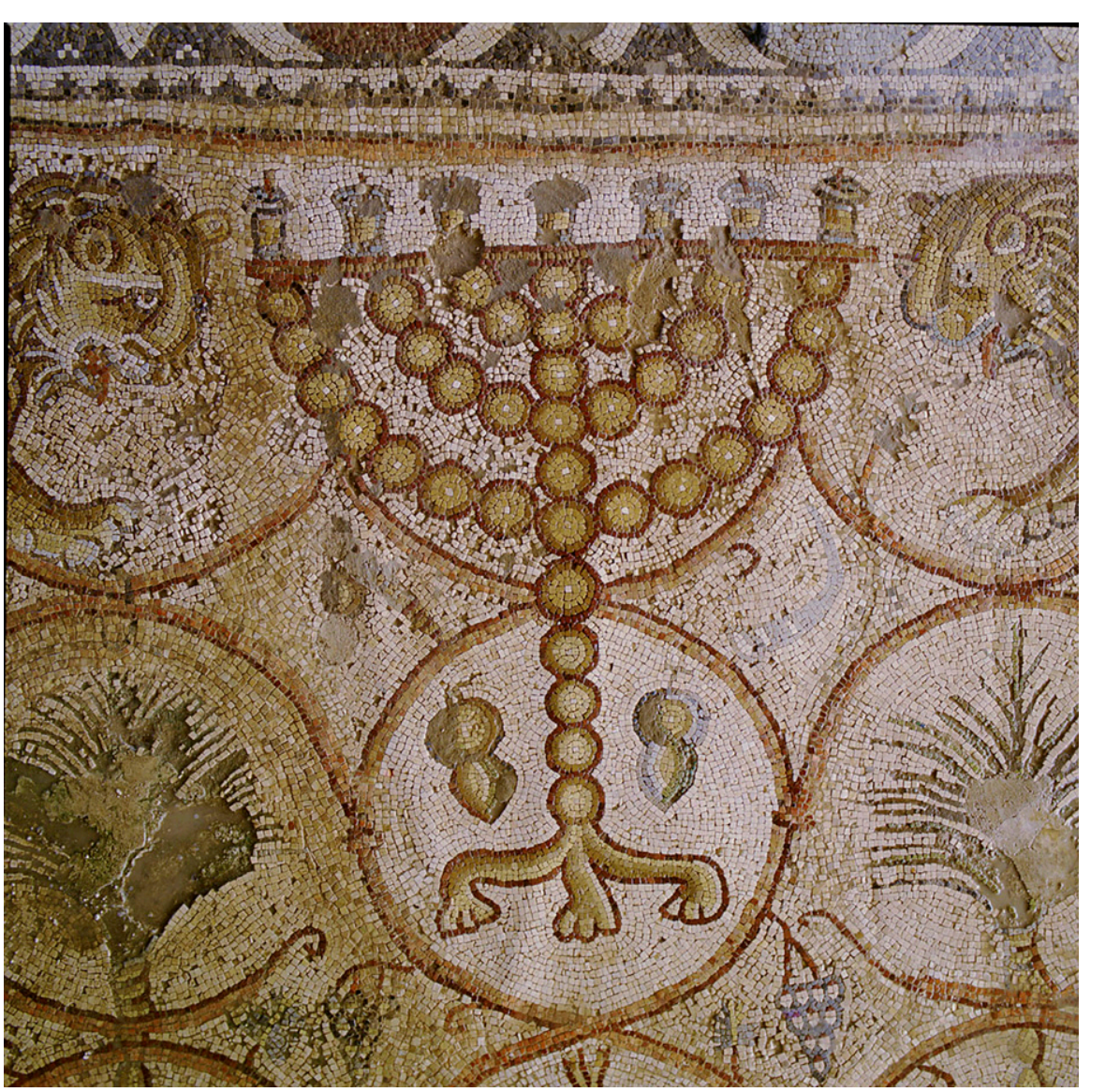

Fig. 3. Two citron fruits alongside a menorah in a magnificent mosaic from the sixth century AD Maon Synagogue (Negev Desert, Israel). Symptoms of viroid infection are notable here as well. Photograph by Clara Amit was made available thanks to the courtesy of the Israel Antiquities Authority.

a reasonable conviction, much older cases of citrus viroid disease infections in citrus trees growing in the Near East almost two millennia ago (Bar-Joseph, 1996).

Summary and conclusions about the western diffusion of $C$. medica. C. medica's area of origin, like that of all other citrus forms, lies in southern or eastern Asia. Yet, Weisskopf and Fuller (2013) suggested that citron originated in the westernmost area in comparison with other citrus species, probably in the central Himalayan foothills, where it was first domesticated (Fig. 1A). Another unique characteristic of citron in comparison with other citrus species is that it has a very thick albedo. This feature allows citron a long shelf life, and therefore, this fruit was probably suitable for long-distance trading. These two distinctive characteristics (westernmost origin and relatively long preservation) may be part of the explanation why the citron was the first citrus crop to immigrate westwards. Indeed, it appears that the citron was considered a valuable commodity since antiquity because of its healing qualities, symbolic use, pleasant odor, and its rarity so that only the rich could have afforded it (e.g., LiranFrisch, 2016; Zohary et al., 2012). Its spread therefore was helped more by its representation of high social status, its significance in religion, and unique features than by its culinary qualities. 
mentioned in western parts of the Islamic world (Ramón-Laca, 2003). Later in the 12th century $\mathrm{AD}$, a book named Treatise of the Dietetic Properties of the Lemon, in which all the qualities of this fruit are detailed, was written in Egypt by Ibn Jamiya, the physician to Sultan Saladin (Arias and Ramón-Laca, 2005). References from Medieval Cairo Genizah (Lev, 2015) and 13th century AD texts from Quseir (Fig. 1A; Guo, 2004), indicate that lemons were shipped from India to Egypt for medical purposes. Yet, according to van der Veen (2011), there is confusion in references between the lime and the lemon, and therefore, it is not certain which of the two fruit types was imported.

\section{Sour (bitter) orange (C. aurantium)}

The hybridization that resulted in the formation of the sour orange most probably took place in southern China or northern Indo-china (Weisskopf and Fuller, 2013). Based on the detailed textual survey conducted by Ramón-Laca (2003), it seems that the sour orange was introduced to Mesopotamia and the eastern Mediterranean and from there it migrated westward. Its introduction is dated to the 10th century $\mathrm{AD}$ based on various textual evidence; in his book Golden Lawns (dated to the 40s of the 10th century AD), al-Mas 'udi's stated that the sour orange and a kind of "round fruit" (maybe lime?) were brought from India to Oman after the year $912 \mathrm{AD}$ and then to Iraq, Syria, Palestine, and Egypt (Davidson, 2006; Ramón-Laca, 2003 and references therein). Al-Mas'udi's claims that in this migration, the sour orange lost much of its fragrance and color because it did not have the climate or the habitat specific to its place of origin (Calabrese, 1998). The sour orange had been previously cited by Ibn Wahshiyya (1993) in his version of the Nabatean Agriculture, compiled at the beginning of the 10th century. The sour orange, together with the lemon, was also mentioned by Ibn Djuldjul (1992) in his additions to Dioscorides' Materia Medica, compiled in Cordoba between 982 and $994 \mathrm{AD}$.

No doubt the Arabs played a major role in the spread of the sour orange from the 10th century AD onward into Persia, Iraq, Syria, Palestine, and Egypt and apparently later into northern Africa, Sicily, Sardinia, and Spain (Webber, 1967). Indeed the name orange comes from a possible Dravic or Tamil root nurga (meaning fragrant) via Sanskirt nāranga (narunga) and Persian nārang (naranj) to Arabic nārandj; narantsion in late Medieval Greek and to the 14th century Spanish naranja (Davidson, 2006; RamónLaca, 2003). At the end of the 15th century, the Portuguese reported that they found many citrons and sour oranges on the east coast of Africa, but they found these trees only in cultivated gardens. It seems certain, therefore, that the Arabs, who had penetrated Egypt, Syria, Palestine, and North Africa in the first years of their conquests, had taken the sour orange with them (Webber, 1967). Botanical remains of citrus suggested to be of sour orange (yet, the identification of the species level cannot be made with confidence) were recovered from Islamic (mid-11th-13th century AD) Queir al-Qadim in the Egyptian desert (Fig. 1A; van der Veen, 2011).

Based on the occurrence of a fruit with a great resemblance to orange in several Roman mosaics and frescos, Tolkowsky $(1938,1966)$ suggested an earlier arrival of the orange to the Mediterranean. Yet, it is not clear whether the sour or sweet orange is depicted; Tolkowsky assumed that it was the sweet variety. In both a mosaic and a fresco from Pompeii dated to the first century AD, orange fruits were depicted; a mosaic from a Roman villa near Tusculum constructed in $\approx 100$ AD shows a basket of fruits comprising an apple, a lemon, a citron, and two other fruits, suggested by Tolkowsky to be oranges. Yet, when Jashemski et al. (2002: 102) discussed this mosaic, they did not mention the possibility of oranges. Furthermore, within the entire book-The natural History of Pompeii (edited by Jashemski and Meyer, 2002), there is no evidence of any kind of the occurrence of oranges in the ancient gardens of Pompeii and the other Vesuvian sites. In the fourth century mosaic from the Mausoleum of Constantia, citrons, lemons, and oranges are depicted, all of them still attached to freshly cut branches carrying green leaves.

In my opinion, there are two possibilities regarding this artistic evidence: 1 ) the Roman artists were familiar to some extent with the exotic orange fruit, but the tree was not necessarily grown in the western Mediterranean; the artists may have seen the orange during their travels abroad; it is also possible that they were foreign art experts. 2) This artistic evidence represents an early arrival of orange, dated already to the first century AD, especially since some of the depicted oranges have remarkably faithful representation. Its westward migration from eastern Asia into the Roman world seems to reflect its exotic qualities and it therefore migrated as an elite product destined to luxurious Roman gardens. If at that stage it was grown only in the Vesuvius area, it may have vanished following the eruption. It could also have disappeared from Italy several times as a result of destructive freezes, disease, and even political disturbance. It is also known that the acclimatization process of foreign plants sometime involves several introductions, especially in the case of citrus that require careful cultivation. During the Roman period, the trees may have been reintroduced from eastern Asia or from Persia in planting pots just as Pliny mentioned for citron. Its later arrival, which is linked to the Islamic conquest, dated to the 10 th century $\mathrm{AD}$, is as a cash crop, as part of the phenomenon of citriculture.

\section{Lime (C. aurantifolia)}

This natural hybrid of citron and papeda (C. micrantha) originated in the tropics, probably in Malaysia or the East Indian archipelago (Scora, 1975). The first textual evidence of lime cultivation outside Southeast Asia is in a text written by Abū 'l-Jayr and Abū 1-Khayr al-Ishbīīi (1991) from Seville sometime between the 11th and 12th centuries (Ramón-Laca, 2003). The first actual botanical remains also date to the same period; lime fruit remains were recovered from the Islamic site Queir al-Qadim in the eastern Egyptian desert (Fig. 1A) from contexts dated to the 11-13th century AD. The relatively rich assemblage was composed of 38 seeds and 48 rind fragments (van der Veen, 2011). According to van der Veen (2011), these remains represent the only archaeobotanical record for lime in Egypt and possibly the only lime remains which have been found so far in the Mediterranean Basin. Yet, van der Veen (2011) claims that lemon seeds from Medieval Syrian sites (1114 th century $\mathrm{AD}$ ) show great resemblance to the type of Queir al-Qadim's lime seeds and in her opinion were previously misidentified (as lemon instead of lime). Whereas van der Veen claims in high certainty that limes were brought to the eastern desert from other locations in Egypt and were also shipped from India as pickles, Thanheiser et al. (2002) pointed out that citrus trees could have been cultivated in the western Egyptian desert as a garden plant in the oasis. Since no fossil lime pollen grains have ever been found in Egypt, it is difficult to accept or reject either opinion (cultivation vs. shipping). There is of course also a possibility that the two approaches are correct, especially since the remains were found in two different eras (Roman and Islamic periods) and the citrus types (citron vs. lime) are different.

\section{Pummelo (C. maxima)}

This true Citrus species originated under tropical conditions, probably in mainland Southeast Asia (Miller and Gross, 2011; Weisskopf and Fuller, 2013) and the Malay Archipelago (Scora 1975). Its name can be traced back to the Malay word pumpulmas, which may itself have been borrowed from another language. The climate in most of Europe is much too cool for the pummelo, except in warmer areas such as southern Spain, where it was introduced by the Arabs. The first mention of pummelo cultivation in Spain is that of Abū 'l-Jayr and Abū 1-Khayr al-Ishbī1̄i (1991) from Seville, dating between the 11th and the 12th centuries AD (Ramón-Laca, 2003). At the same time, alTignari from Granada also mentioned the pummelo in his writings and so did a little later by Ibn al-'Awwam (1802). In Jacques de Vitry's writings from the early 13th century, it is mentioned that a fruit named poma Adam (Adam's apple, possibly a form of pummelo) occurred in Palestine. This region is also characterized by a relatively warmer climate and is therefore suitable for pummelo cultivation.

\section{Sweet orange (C. sinensis)}

The first mention of the sweet orange in Europe is sometimes said to be in the archives 
of the Italian city of Savona, in 1471. However, Platina (1475, but he prepared his manuscript in the preceding decade) provides a better starting point because he distinguished between sweet and sour orange. Gallesio (1811) concluded from his historical study that the sweet orange probably reached Europe first through the commercial trade route established and maintained by the Genoese. Later, during the 16th century $\mathrm{AD}$, the Portuguese and particularly the travels of circumnavigation to the east carried out by Vasco de Gama contributed much to the spread and popularization of orange growing, by introducing a superior variety. Indeed, in 1498, Vasco de Gama saw in Mombaça "very good oranges, much better than those from Portugal" (Herculano, 1861: 36 ). On the other hand, some images (it is not clear whether they were sweet or sour) are questionably proposed to represent oranges in early Roman art (mentioned previously in relation to the sour orange).

\section{Mandarin (C. reticulata)}

Mandarin ( $C$. reticulata), a true Citrus species, originated in China and northeast India (Fig. 1A; Scora, 1975; Spiegel-Roy and Goldschmidt, 1996) and was cultivated in its area of origin from a very early date, but it was the last major citrus fruit to travel to the west. The first specimen of a mandarin cultivar was brought from China to England in 1805 and then to Italy, where it became well established before 1850 . From Italy, its cultivation spread quickly to other Mediterranean countries (Davidson, 2006). Other mandarin cultivars reached the Mediterranean Basin afterward.

\section{Summary}

It is obvious that if studied intensively, each particular citrus species would reveal a number of different dispersal circumstances and that many people were involved in the introduction of citrus fruits from Southeast Asia to the Mediterranean. The type of evidence derives from three main sources: botanical remains, art artifacts, and ancient texts. This essay shows that each type of evidence should be evaluated carefully for its authenticity and significance before a conclusion can be drawn.

After excluding all the uncertain evidence, the citrus migration westward can be summarized as follows: 1) The citron was the first citrus fruit to reach the Mediterranean, which is why the whole group of fruits is named after one of its less economically important members. It was introduced to the Eastern Mediterranean around the fifth and fourth centuries BC. 2) The citron and the lemon (which was introduced to the west at least four centuries later) were considered as elite products at that time. This means that for more than a millennium, citron and lemon were the only citrus fruits known in the Mediterranean Basin. 3) Sour orange, lime, and pummelo were introduced to the west by the Muslims probably via Sicily and the
Iberian Peninsula, beginning in the 10th century $\mathrm{AD}$. It is clear that the Muslims played a crucial role in the dispersal of cultivated citrus in Northern Africa and Southern Europe, as evident also from the common names of many of the citrus types which were derived from Arabic, following an earlier diversification in Southeast Asia. This was possible because they controlled extensive territory and commerce routes reaching from India to the Mediterranean. 4) The introduction of the sweet orange is dated to the 15 th century $\mathrm{AD}$; its arrival is linked probably with the trade route established by the Genoese and later (since the 16 century AD) by the Portuguese. 5) The mandarin was introduced to the region only at the beginning of the 19th century.

Interestingly, the citron that was the first citrus to arrive in the Mediterranean can be grown from seeds and actually it is required that it be grown in that way by religious Jews to be kosher for the Tabernacles ceremony. The other, later arriving citrus species, are grafted to keep their desired fruit characteristics.

\section{Literature Cited}

Abū 'l-Jayr and Abū 'l-Khayr al-Ishbīlī. 1991. Kitāb al-filāha. Tratado de agricultura. Edited and translated into Spanish by J. M. Carabaza, Ministerio de Asuntos Exteriores, Agencia Española de Cooperación Internacional, Instituto de Cooperación con el Mundo Árabe, Madrid.

Amar, Z. 2009. The four species anthology. Oren Press Production, Tel Aviv, Israel (in Hebrew).

Amar, Z. 2012. Flora of the bible. Rubin Mass, Jerusalem.

Andrews, A.C. 1961. Acclimatization of citrus fruits in the Mediterranean region. Art Hist. 31:35-46.

Arias, B.A. and L. Ramón-Laca. 2005. Pharmacological properties of Citrus and their ancient and medieval uses in the Mediterranean region. J. Ethnopharmacol. 97:89-95.

Bar-Joseph, M. 1996. A contribution to the natural history of viroids. Proc. 13th IOCV Conf. 226-229.

Barkley, N.A., M.L. Roose, R.R. Krueger, and C.T. Federici. 2006. Assessing genetic diversity and population structure in a citrus germplasm collection utilizing simple sequence repeat markers (SSRs). Theor. Appl. Genet. 112: 1519-1531.

Barrett, H.C. and A.M. Rhodes. 1976. A numerical taxonomic study of affinity relationships in cultivated citrus and its close relatives. Syst. Bot. 1:105-136.

Ben-Sasson, R. 2012. Botanics and iconography images of the lulav and the etrog. Art Judaica $8: 7-22$.

Bonavia, E. 1894. The flora of the Assyrian monuments and its outcomes. Westminster, London.

Bui Thi, M. and M. Girard. 2014. Citrus (Rutaceae) was present in the western Mediterranean in antiquity, p. 170-174. In: A. Chevalier, E. Marinova, and L. Pena-Chocarro (eds.). Plants and people: Choices and diversity through time. Oxbow Books, Oxford.

Calabrese, F. 1998. The fascinating history of citrus fruit. L'EPOS, Palermo.

Ciaraldi, M. 2007. People and plants in ancient Pompeii: A new approach to urbanism from the microscope room. The use of plant resources at Pompeii and in the Pompeian area from the 6th century $\mathrm{BC}$ to $\mathrm{AD} 79$. Accordia Research Institute, Univ. of London, London.

Coubray, S. 1996. Restes végétaux du dépôt votif. Atti Mem. Soc. Magna Grecia 3:105-108.

Coubray, S., V. Zech-Matterne, and A. Mazurier. 2010. The earliest remains of a Citrus fruit from a western Mediterranean archaeological context? A microtomographic-based reassessment. C. R. Palevol 9:277-282.

Curk, F., F. Ollitrault, A. Garcia-Lor, F. Luro, L. Navarro, and P. Ollitrault. 2016. Phylogenetic origin of limes and lemons revealed by cytoplasmic and nuclear markers. Ann. Bot. (Lond.) 117:565-583.

Dalechamps, J. 1587. Historia generalis plantarum 1. G. Roville, Lyon.

Davidson, A. 2006. The Oxford companion to food. 2nd ed. Oxford Univ. Press.

de l'Écluse, C. 1601. Rariorum plantarum historia. C. Plantin, Antwerp.

Dimbleby, G.W. and E. Grüger. 2002. Pollen analysis of soil samples from the A.D. 79 level: Pompeii, Oplontis, and Boscoreale, p. 181216. In: W. Jashemski and F.G. Meyer (eds.). The natural history of Pompeii. Cambridge Univ. Press, Cambridge.

Federici, C.T., D.Q. Fang, R.W. Scora, and M.L. Roose. 1998. Phylogenetic relationships within the genus Citrus (Rutaceae) and related genera as revealed by RFLP and RAPD analysis. Theor. Appl. Genet. 96:812-822.

Ferrari, G.B. 1646. Hesperides sive de malorum aureorum cultura et usu libri quatuor. $\mathrm{H}$. Schens, Rome.

Fiorentino, G. and G. Marinò. 2008. Analisi archeobotaniche preliminari al Tempio di Venere di Pompei, p. 527-528. In: P.G. Guzzo and M.P. Guidobaldi (eds.). Nuove ricerche archeologiche nell'area vesuviana (scavi 2003-2006). Atti del Convegno Internazionale, Roma 1-3 febbraio 2007. L'Erma di Bretschneider, Roma.

Fuller, D.Q., N. Boivin, T. Hoogervorst, and R. Allaby. 2011. Across the Indian Ocean: The prehistoric movement of plants and animals. Antiquity 85:544-558.

Gallesio, G. 1811. Traité du citrus. L. Fantin, Paris.

Gmitter, F.G., Jr. and X. Hu. 1990. The possible role of Yunnan, China, in the origin of contemporary Citrus species (Rutaceae). Econ. Bot. 44:267-277.

Goldschmidt, E.E. 1976. Factors determining the shape of citrons. Isr. J. Bot. 25:34-40.

Grüger, E. and B. Thulin. 1998. First results of biostratigraphical investigations of Lago d'Averno near Naples relating to the period 800 BC- 800 AD. Quat. Intl. 47:35-40.

Grüger, E., B. Thulin, J. Müller, J. Schneider, J. Alefs, and F.W. Welter-Schultes. 2002. Environmental changes in and around Lake Avernus in Greek and Roman times: A study of the plant and animal remains preserved in the lake's sediment, p. 240-273. In: W. Jashemski and F.G. Meyer (eds.). The natural history of Pompeii. Cambridge Univ. Press, Cambridge.

Guo, L. 2004. Commerce, culture, and community in a Red Sea port in the thirteenth century: The Arabic documents from Quseir (Vol. 52). Brill, Leiden.

Gur, A. 1974. Fruits of the land of Israel. Hakibbutz Hameuhad, Tel Aviv, Israel (in Hebrew).

Herculano, A. 1861. Roteiro da viagem de Vasco da Gama en MCCCCXCVII. Imprenta Nacional, Lisboa.

Hjelmqvist, H. 1979. Some economic plants and weeds from the Bronze Age of Cyprus. Stud. Mediterr. Archeol. 45:110-117. 
Ibn al-'Awwam. 1802. Kitāb al-filāha. Libro de agricultura 1. In: J.A. Banqueri, Imprenta Real, Madrid.

Ibn Djuldjul. 1992. Maqāla tāmina. Tratado octavo. In: I. Garijo (ed.). Univ. de Córdoba, Cordoba.

Ibn Wahshiyya. 1993. Al-filā a n-nabatīyya. In: T. Fahd (ed.). L'agriculture Nabatéenne. Institut Français de Damas, Damascus.

Isaac, E. 1959. Influence of Religion on the Spread of Citrus. Sci. 129:179-186.

Jashemski, W.F. and F.G. Meyer (eds.). 2002. The natural history of Pompeii. Cambridge Univ. Press, Cambridge.

Jashemski, W.F., F.G. Meyer, and M. Ricciardi. 2002. Plants: Evidence from wall paintings, mosaics, sculpture, plant remains, graffiti, inscription and ancient authors, p. 80-180. In: W.F. Jashemski, and F.G. Meyer (eds.). The natural history of Pompeii. Cambridge Univ. Press, Cambridge.

Kraeling, C.H. 1956. The excavations at DuraEuropos: The synagogue. Yale Univ., New Haven, p. 56-62.

Langgut, D. 2015. Prestigious fruit trees in ancient Israel: First palynological evidence for growing Juglans regia and Citrus medica. Isr. J. Plant Sci. 62:98-110.

Langgut, D., Y. Gadot, N. Porat, and O. Lipschits. 2013. Fossil pollen reveals the secrets of royal Persian garden in Ramat Rahel (Jerusalem). Palynol. 37:115-129.

Langgut, D., K. Gleason, and B. Burrell. 2015. Pollen analysis as evidence for Herod's royal garden at the promontory palace, Caesarea. Israel J. Plant Sci. 62:111-121.

Langgut, D. and O. Lipschits. 2017. Dry Climate during the Babylonian and the Early Persian Period and its Impact on the Creation of Idumea. Transeuphraténe 49:141-172.

Lev, E. 2015. Botanical view of the use of plants in medieval medicine in the eastern Mediterranean according to the Cairo Genizah. Isr. J. Plant Sci. 62:122-140.

Lipschits, O., Y. Gadot, and D. Langgut. 2012. The riddle of Ramat Rahel: The archaeology of a royal edifice from the Persian periods. Transeuphraten 41:57-79.

Liran, N. 2013. The etrog in the Jewish culture: Interdisciplinary study of the ritual object throughout the ages. University Haifa, Haifa, PhD Diss. in Hebrew, with English Abstr.

Liran-Frisch, N. 2016. Etrog of the heart: Essay on the four species. Resling, Tel Aviv, Israel (in Hebrew).

Loret, V. 1891. Le cédratier dans l'antiquité. E. Leroux, Paris.

Mariotti-Lippi, M. 2000. The garden of the "Casa delle Nozze di Ercole ed Ebe" in Pompeii (Italy): Palynological investigations. Plant Biosyst. 134:205-211.
Miller, A.J. and B.L. Gross. 2011. From forest to field: Perennial fruit crop domestication. Amer. J. Bot. 98:1389-1414.

Nicolosi, E., Z.N. Deng, A. Gentile, S. La Malfa, G. Continella, and E. Tribulato. 2000. Citrus phylogeny and genetic origin of important species as investigated by molecular markers. Theor. Appl. Genet. 100:1155-1166.

Nicolosi, E., S. La Malfa, M. El-Otmani, M. Negbi, and E.E. Goldschmidt. 2005. The search for the authentic citron (Citrus medica L.): Historic and genetic analysis. HortSci. 40:1963-1968.

Pagnoux, C., A. Celant, S. Coubray, G. Fiorentino, and V. Zech-Matterne. 2013. The introduction of citrus to Italy, with reference to the identification problems of seed remains. Veg. Hist. Archaeobot. 22:421-438.

Pang, X.M., C.G. Hu, and X.X. Deng. 2007. Phylogenetic relationships within Citrus and its related genera as inferred from AFLP markers. Genet. Resources Crop Evol. 54:429-436.

Ramón-Laca, L. 2003. The introduction of cultivated citrus to Europe via Northern Africa and the Iberian peninsula. Econ. Bot. 57:502-514.

Russo-Ermolli, E. and E. Messager. The gardens of Villa A at Oplontis through pollen and phytolith analysis of soil samples. In: J.R. Clarke and N.K. Muntasser (eds.). Villa A ("of Poppaea") at Oplontis (Torre Annunziata, Italy), volume 1: The ancient setting and modern rediscovery. ACLS Humanities E-Books Series, New York, (in press).

Russo-Ermolli, E.R., P. Romano, M.R. Ruello, and M.R.B. Lumaga. 2014. The natural and cultural landscape of Naples (southern Italy) during the Graeco-Roman and Late Antique periods. J. Arch. Sci. 42:399-411.

Russo-Ermolli, E., B. Menale, and M.R.B. Lumaga. Pollen morphology of Citrus medica versus Citrus x limon. In: V. Zech, G. Fiorentino, and S. Coubray (eds.). The history and archaeology of the citrus fruit from the Far East to the Mediterranean: Introductions, diversifications, uses, (in press).

Schwartz, D. 2005. The second book of Maccabees: Introduction, Hebrew translation and commentary. Yad Ben Zvi, Jerusalem.

Schweingruber, F.H. 1990. Anatomy of European woods: An atlas for the identification of European trees, shrubs and dwarf shrubs. Edition Paul Haupt, Bern.

Scora, R.W. 1975. On the history and origin of citrus. Bul. Torrey Bot. Club 102.

Spiegel-Roy, P. and E.E. Goldschmidt. 1996. Biology of citrus. Cambridge Univ. Press, Cambridge and New York.

Sussman, V. 1972. Nerot heres me 'uttarim (ornamented Jewish oil lamps). The Bialik Institute, Jerusalem.

Thanheiser, U., J. Walter, and C.A. Hope. 2002. Roman agriculture and gardening in Egypt as seen from Kellis, p. 299-310. In: C.A. Hope and G.E. Bowen (eds.). Dakhleh oasis project:
Preliminary report on the 1994-1995 to 19981999 field seasons. Oxbow Books, Oxford.

Theophrastus. 1916. Enquiry into plants. English translation by A.F. Hort. Loeb Classical Library, Cambridge, MA.

Tolkowsky, S. 1938. Hesperides: A history of the culture and use of citrus fruits. John Bale, Sons \& Curnow, London.

Tolkowsky, S. 1966. Citrus fruits - their origin and history throughout the world. The Bialik Institute, Jerusalem (in Hebrew).

van der Veen, M. 1996. The plant remains from Mons Claudianus, a Roman quarry settlement in the eastern desert of Egypt-An interim report. Veg. Hist. Archaeobot. 5:137-141.

van der Veen, M. 2001. The botanical evidence, p. 174-247. In: V.A. Maxfield and D.P.S. Peacock (eds.). Survey and excavations at Mons Claudianus 1987-1993, volume 2. Institut Français d'Archéologie Orientale du Caire, Cairo.

van der Veen, M. 2011. Consumption, trade and innovation: Exploring the botanical remains from the Roman and Islamic ports at Quseir al-Qadim, Egypt. Africa Magna Verlag, Frankfurt.

van der Veen, M. and H. Tabinor. 2007. Food, fodder and fuel at Mons Porphyrites: The botanical evidence, p. 83-142. In: V.A. Maxfield, and D.P.S. Peacock (eds.). The Roman imperial quarries, survey and excavation at Mons Porphyrites 1994-1998, volume 2. Egypt Exploration Society, London.

van Zeist, W., S. Bottema, and M. van der Veen. 2001. Diet and vegetation at ancient Carthage: The archaeobotanical evidence. Groningen Institute of Archaeology, Groningen.

Watson, A.M. 1983. Agricultural innovation in the early Islamic world. Cambridge Univ. Press, Cambridge.

Webber, H.J. 1967. History and development of the citrus industry, p. 1-39. In: W. Reuther, H.J. Webber, and L.D. Batchelor (eds.). The citrus industry 1 . History, world distribution, botany, and varieties. Univ. of California, Berkeley.

Weisskopf, A. and D. Fuller. 2013. Citrus fruits: Origins and developments, p. 1479-1483. In: C. Smith (ed.). Encycl. of global arch. Springer, Berlin, Germany.

Wu, G.A., S. Prochnik, J. Jenkins, J. Salse, U. Hellsten, F. Murat, and M.A. Machado. 2014. Sequencing of diverse mandarin, pummelo and orange genomes reveals complex history of admixture during citrus domestication. Nat. Biotechnol. 32:656-662.

Xianghong, Y.Y.K.Y.Z. 1982. Studies on the pollen morphology of citrus plants. Zhongguo Nong Ye Ke Xue 112:88-93.

Zohary, D., M. Hopf, and E. Weiss. 2012. Domestication of plants in the old world. 4th ed. Oxford Univ. Press, Oxford. 